\title{
Examining the Bodhisattva's Brain
}

\author{
Bronwyn Finnigan \\ Marquette University \\ bronwyn.finnigan@marquette.edu
}

Forthcoming in Zygon, 2014. Draft only. Please cite published version.

There is growing interest in Asian traditions amongst Western-trained philosophers. A major contributing factor has been the publication in the past twenty years of several bold philosophical works that critically engage with positions advanced by Asian philosophical thinkers. The Bodhisattva's Brain [henceforth, BB] contributes to this emergent trend. BB is divided between two main lines of contention. The first half of the book critiques the recent 'science of happiness' literature, which correlates happiness with Buddhism on the basis of certain neurological studies. The second half aims to introduce analytic philosophers and " $21^{\text {st }}$ century scientifically informed secular thinkers" (xi) to the "deep structure of the metaphysics, epistemology and ethics of Buddhist philosophy" (xiii). Flanagan's methodology for this introduction is reconstructive (what he calls 'cosmopolitan') rather than strictly exegetical. That is, he aims to defend a conception of Buddhism that excludes reference to supernatural entities and philosophical commitments, which, in his view, have questionable epistemic warrant. Flanagan's Buddhism is intended to be "naturalized, tamed, and made compatible with a philosophy that is empirically responsible, and that does not embrace the low epistemic standards that permit all manner of superstition and nonsense." (xiii)

For the secular Western thinker with little familiarity with Buddhist thought, I believe BB succeeds in providing access to some of the central philosophical ideas in the Buddhist tradition. I also believe, and will argue below, that Flanagan's critique of the 'science of happiness' literature is strong, compelling and should be accepted by philosophically trained and untrained thinkers alike. Despite these clear strengths, I believe and shall attempt to demonstrate that the second half of BB is problematically limited in its critical engagement with Buddhist thought in ways that may not satisfy the analytically trained philosophical reader.

In the opening chapters of BB, Flanagan offers a compelling critique of recent 'science of happiness' literature, of which he appears to have played some role in initiating. According to Flanagan, a central hypothesis of this literature is that there is a connection between Buddhism and happiness. This is thought to be confirmed by certain neurological studies conducted on Buddhist practitioners. Flanagan convincingly argues that this literature is insufficiently reflective about its presuppositions. He queries and challenges the object of these studies. Are they identifying happiness as a property of Buddhism (Does it make sense to attribute happiness to a tradition? Is this meant to apply to all Buddhist sub-traditions?); of Buddhists (What is it to be Buddhist? Is self-identification sufficient for attributing happiness); or of practicing Buddhists (What is it to practice Buddhism? Must one meditate? If so, what kind of meditation, and how much, is required for the attribution of happiness?). Flanagan also challenges the evidence provided by the relevant studies (Can it be legitimately generalized from a specific, localized case to all Buddhists and contrasted with all non-Buddhists?) Moreover, the studies on which this hypothesis rests assume a correlation between certain kinds of neurological activity with certain kinds of phenomenal states (viz. certain degrees of sensory 
pleasure). Flanagan rightly points out that this assumed connection has yet to be scientifically established.

The challenge at the heart of Flanagan's critique, however, concerns the object of measurement assumed by these studies (viz. happiness). 'What is happiness?' is a question of much philosophical import. Even were we to grant that certain activities in the brain do, in fact, correlate with certain peaks of phenomenal sensory pleasure, one need not accept such a simplistic conception of happiness. Flanagan insists that if one's conception of happiness incorporates cognitive content (e.g. a sense of meaning or self-worth), then generalizing the presence of happiness from these neurological studies becomes much less plausible. He is undoubtedly right about this. The problem is exacerbated if one accepts an Aristotelian eudaimonistic conception of happiness, according to which happiness is a form of living constituted by various virtues of character and intellect. Simply measuring the brain activity of certain subjects in certain contexts is not going to tell you whether they are living a good human life, so conceived.

While I am convinced by Flanagan on this issue, it seems to me that the point can be well made independently of whether the subjects of the study are Buddhists. Flanagan has a more ambitious target for his claim, however. The objective of the second half of $\mathrm{BB}$ is to demonstrate that the Buddhist conception of happiness is, in fact, much more sophisticated than these neurological studies assume. More specifically, that it is similar to Aristotelian eudaimonia in several crucial respects. Despite the clear strengths of the first half of BB, I find Flanagan's positive message concerning the Buddhist conception of happiness and the nature of Buddhist ethics to be somewhat less persuasive.

I have both general and more specific reservations. In general, it seems to me that Flanagan's engagement with Buddhist thought lacks the rigor that he demands from his 'science of happiness' opponents. Flanagan is ferocious in his insistence on conceptual precision and high epistemic standards. By contrast, he permits himself much scholarly leniency in his characterization of Buddhism. This is a problem given that one of Flanagan's stated objectives is to extract what is "truthful and useful in Buddhism" and introduce scientifically informed thinkers and analytic philosophers to the "deep structure of the metaphysics, epistemology and ethics of Buddhist philosophy" (xiii). In providing this introduction, Flanagan does not make direct appeal to any Buddhist philosophical literature, whether historical and contemporary, of which there is a considerable amount. Instead, he appeals to the popular claims of Buddhist practitioners with whom he has engaged in dialogue. The only textual evidence provided for his characterization of Buddhist thought is the popular discourses of the Dalai Lama. Despite the high level of the Dalai Lama's knowledge about (particular forms of) Buddhism, his popular discourses are typically tailored for his Western audience. This source of evidence should give the reader reason to pause about the depth of Buddhist philosophy to which they are being introduced.

More importantly, the lack of the reference to credible sources also provides grounds for questioning the suggestion, inadvertently made in BB, that the Buddhist philosophical tradition somehow lacks philosophical rigor. Whether intended or not, this seems to be suggested by Flanagan's stated aim of making Buddhism "compatible with a philosophy that is empirically responsible, and that does not embrace the low epistemic standards that permit all manner of superstition and nonsense." (xiii) This suggests that Buddhism has low epistemic standards, which permit superstition and nonsense. There is a vast amount of philosophical theorization, argumentation, and commentary between the superstitious elements that 
Flanagan seeks to excise and the popular discourses of the Dalai Lama. Indeed, it is arguable that certain superstitious elements of the Buddhist tradition as popularly practiced do not even satisfy the epistemic standards internal to the Buddhist tradition. The epistemic standards of Buddhist tradition are quite high and it is not clear that Flanagan has adequately taken this into account in his representation of Buddhist views.

Now, some care is needed in making this general critique as Flanagan might be said to have a methodological justification for his approach. He explicitly and repeatedly claims to be offering his own "anachronistic, ethnocentric and cosmopolitan" (6) reconstruction of Buddhist thought. We are being presented with "Buddhism, as I understand it" (170), a conception that, in Flanagan's view, captures "the spirit that runs through Buddhisms" (xii), without necessarily assuming that any given Buddhist actually holds his reconstructed view.

I am very sympathetic to rational reconstruction as a methodology. Much of what is so exciting about recent philosophical engagements with Buddhism involves setting aside certain hermeneutic burdens to critically analyze the logical implications and possibilities of Buddhist philosophical positions made available in translations and commentaries. That Flanagan is presenting his own rationally reconstructed conception of Buddhism is not, in itself, a problem. However, reconstructive analyses necessarily involve taking certain claims as their starting point or analysans. For Flanagan's account to be a 'naturalized and tamed' version of Buddhism he must assume certain views to be legitimately and genuinely representative of Buddhist thought. I have certain difficulties with Flanagan's assumed starting place. Articulating these difficulties will lead to my more particular and substantive concerns with Flanagan's conception of Buddhist happiness and Buddhist ethics.

Flanagan grounds his cosmopolitan engagement with Buddhism on, what he claims to be, a "common core conception" (15) on which "all Buddhist sects agree" (121) and which is "shared by all/most forms of Buddhism" (19). What is this common conception? According to Flanagan, it is a conception of the goal of Buddhist practice as a form of eudaimonia, understood as involving a tranquil state of mind that comes from a sense that one is living a worthwhile human life caused or constituted by wisdom, virtue and mindfulness. Little evidence is given to support Flanagan's claim that (a) all Buddhists have a shared common conception of the goal of Buddhist practice, and (b) that it is a Buddhist form of eudaimonia. These claims are worth keeping distinct.

It may not seem that much evidence is required for the claim that all Buddhists have a shared common conception of the goal of Buddhist practice. Each Buddhist philosophical tradition and each Buddhist practitioner seeks to be consistent with the Buddha's teachings. Central to the Buddha's teachings were the Four Noble Truths. They are (the truth of or about) suffering; the cause of suffering; the cessation of suffering; and the pathway to the cessation of suffering (viz. the Eightfold Path). The Eightfold Path consists of right view, right intention, right speech, right action, right livelihood, right mindfulness and right concentration. It is fair to say that all Buddhists qua Buddhist accept the Four Noble Truths and all Buddhist practitioners qua Buddhist practitioners seek to implement the Eightfold Path in their lives. These teachings may thus be legitimately said to constitute a shared common conception on which all Buddhist sects agree. There is arguably little need for textual evidence as this much can be found in any introduction to Buddhism. The acceptance of these claims, however, is merely the starting place for the philosophical richness of the Buddhist tradition. Explaining what each of these claims amount to, how they are best 
to be understood, and what they presuppose metaphysically, epistemologically and in terms of philosophy of mind is the source of a vast amount of disagreement between Buddhist philosophical traditions and between Buddhists.

Now it might be thought that acceptance of this point is entirely consistent with Flanagan's methodology. He can accept that historical and traditional Buddhist philosophers disagree over how best to characterize and/or systematize the Buddha's teachings but insist that he, like these very same philosophers, is simply offering his own account based on the same starting assumptions. This seems to be precisely the point of his introductory remark about avoiding sectarian disagreement and offering an account aimed at capturing the spirit of Buddhism according to his own anachronistic, ethnocentric, cosmopolitan understanding.

I do not believe Flanagan can so easily avoid engaging with Buddhist philosophical traditions, however. He does not merely claim that all Buddhists accept the Four Noble Truths and the Eightfold Path. He forwards a particular analysis of these truths and insists that these commitments, so analyzed, constitute the core of Buddhist thought. That is, he claims that all Buddhists agree that the goal of Buddhist practice is a form of eudaimonia, understood as a human form of life that involves a tranquil state of mind that comes from a sense of living a worthwhile human life and which is caused or constituted by wisdom, virtue and mindfulness. This is by no means a universal conception of the goal of the Buddhist path. As Flanagan recognizes, in the earliest recordings of the Buddha's teachings, the goal of the Buddhist path is presented largely in negative terms; viz. the cessation of suffering. It is an open question how best to conceive its positive counter-part. Eudaimonia might be a plausible reconstruction of what it ought to be, given various claims and beliefs shared by Buddhist sects. But it is not the only one. Charles Goodman, for instance, defends a consequentialist alternative (cf. Goodman 2009). Flanagan might be right in his reconstruction and Goodman wrong but the case needs to be made. Flanagan gives no indication that there may be disagreement with his particular analysis of Buddhist thought and provides little argument in its defense. ${ }^{1}$

There is a more substantive problem, however. Flanagan does not merely provide a reconstructed account of the goal of Buddhist practice. He also provides a summarized account of Buddhist metaphysics and epistemology. In presenting this summary, Flanagan picks and chooses from the Buddhist philosophical tradition. For the most part, he draws on recent reductive metaphysical analyses of Abhidharma and Madhyamaka (cf. Siderits 2003) and repackages them as a form of Lockeian reductionism. These reductive metaphysical commitments are in direct tension with some of the ideas presupposed by Flanagan's eudaimonistic analysis of Buddhism. Demonstrating this fact will be the purpose of what follows. My aim will be to show that when Flanagan's Buddhism Naturalized is put into dialogue with the Buddhist philosophical tradition, problems arise that would need to be resolved by an adequate defense. Thus, not only does BB offer little defense of Flanagan's reconstruction of Buddhist ethics, but such a defense will be problematic. I will conclude by suggesting that these are problems to which a trained analytic philosopher may be sensitive and thus may leave BB's intended audience dissatisfied with its depth of engagement.

The particular issue on which I will focus concerns Flanagan's characterization of the Buddhist version of eudaimonia that he claims to be accepted by all Buddhist sects as a common core conception. He characterizes this conception

\footnotetext{
${ }^{1}$ Flanagan claims that Goodman's consequentialism can be (unproblematically?) combined with his eudaimonistic account. Whether or not he is right about this (and I suspect he is not) it cannot be merely asserted, it needs to be established with evidence and an argument.
} 
of the goal of Buddhist practice as "caused or constituted" by wisdom, virtue and mindfulness. This disjunction of 'causes or constituents' masks a philosophical problem that would need to be resolved by someone who seeks to defend a eudaimonistic conception of the Buddhist path.

Despite Flanagan's claim that Buddhism is a distinctive normative ethical theory (20), and despite the fact that Buddhist texts are filled with categorizations of actions, mental states and qualities as good and bad, Buddhist philosophers did not attempt to unify their normative claims into systematic ethical theories. Within the Buddhist canon there are often competing ethical claims and practices but no attempt to unify them under guiding normative principles for right action. ${ }^{2}$ There is also a diversity of competing epistemological and metaphysical positions that permit various ways of reconstructing their meta-ethical foundations (see Finnigan 2010-11). In the past twenty years or so, however, several interpretive attempts have been made to reconstruct a plausible Buddhist ethic. Damian Keown defends a eudaemonistic virtue ethical interpretation. One of the major criticisms of this approach concerns its alleged presupposition of a substantive 'self' as the mereological sum of the various virtue characteristics or qualities that are thought to persist or develop over the duration of a human life. This, it is argued, opposes the central Buddhist doctrine of no-self (anätman). This criticism is leveled by contemporary Buddhist metaphysical reductionists; most notably, Mark Siderits (2003). Buddhist metaphysical reductionists accept and develop Abhidharma metaphysical arguments against the reality of substances and against substances conceived as supervening on persons or person-substrata (i.e. pudgala). According to Abhidharma, as exemplified by Vasubandhu in his Abhidharmakośa, there are no such substances in which such qualities could inhere and could count as properties thereof. Mereological wholes are simply mental fabrications or constructions from a reductive ontological base of atomic 'dharmas' in causal relations. In the reductive ontology of Abhidharma, constitution qua mereological sum is considered to be an unreal, mentally fabricated relation. Causal efficacy, however, is considered to be a legitimate mark of the real (see Siderits 2003, AKB).

Flanagan accepts a reductive characterization of the Buddhist metaphysics of personal identity. He goes so far as to champion Siderits as one who would make the scientific naturalist proud (28). From the perspective of Abhidharma reductive ontology, however, Flanagan's characterization of the good life as "caused or constituted" by certain qualities is, at best, a hedged bet. While causation is readily admissible by this ontology (though even this maybe challenged, as we will see below), an argument is needed to defend the constitution relation as a viable and irreducibly compatible disjunct. Such need might be avoided if this disjunct is foregone. However, I submit that eudaimonia does not make sense without a constitution relation and eudaimonia is central to Flanagan's characterization of Buddhist ethical thought. Without an adequate defense of its legitimacy it is vulnerable to the consequentialist charge that it is reducible to consequentialism. That is, it could be argued that the value of certain qualities of intellect and value are not

\footnotetext{
2 This is particularly apparent in Buddhist canonical and non-canonical views towards violence. (see Sperling 1996, Jerryson and Juergensmeyer eds. 2010). It might be possible to rationalize away such inconsistency, as merely apparent, by appealing to some general ethical principles (the Four Noble Truths perhaps). My point, here, is simply to point out that there is (at least apparent) inconsistency in normative views across the Buddhist canon and thus argumentation is required to establish that Buddhism is a normative ethical theory or presupposes some normative ethical theory. For discussions of the Buddhist views on violence, see
} 
justified relative to their status as joint constituents of living a good life. Rather, their value is justified entirely in causal relation to the production of some independently valuable state; viz. happiness or the absence of suffering, reductively conceived.

There are ways in which a Buddhist eudaemonist might resist this reductive move and thus preserve the constitutive complexity of eudaimonia. One possibility is to deny that the relevant constitution relation is mereological and insist, instead, that it is teleological and thereby legitimately causal per Abhidharma. This approach is controversial and would require some work. It would require investigating the limits of the Abhidharma conception of causation. It would also involve re-legitimizing an Aristotelian conception of causation that was abandoned by the early moderns in favor of a singular notion of efficient causation. While challenging, this latter requirement is not implausible. In contemporary philosophy of biology, a legitimately causal sense of teleology is steadily regaining some ground via the notion of a biological function (see Ariew and Cummins et.al. 2002, Godfrey-Smith 1993, 1994). Admittedly, a robust defense of a sense of teleology that extended to virtues of character would require a sophisticated account of dispositions. This is not an inconsiderable task given current literature on finks and masks (see Choi 2012). Nevertheless, it would be in principle compatible with an ontology that only permitted causal relations.

Although this might be a possible way of reconciling a eudaemonist analysis of Buddhist ethics with the acceptance of an Abhidharma reductive ontology, it does involve assuming the Abhidharma reductive ontology. This ontology assumes a reductive base of causally related simple entities that have essential properties or selfnatures (svabhāva). These 'self-natures' serve both to individuate these entities and provide their unique source of existence. To have svabhavva is to exist independently of anything else. According to Madhyamaka arguments, informed by Nāgārjuna, the Abhidharma ontology is inconsistent in its assumed reductive base (see Nāgārjuna, MMK, Cowherds 2010). Moreover, few contemporary metaphysicians (let alone physicists) would accept this particular form of essentialist ontology (see Westerhoff 2009).

An alternative strategy available to the eudaemonist is to appeal to Madhyamaka rather than Ābhidharmika arguments. In particular, they could utilize a specifically Madhyamaka version of the Buddhist distinction between ultimate and conventional truths and argue for the conventional reality of persons as mereological wholes of variously developing qualities and characteristics. A eudaemonist could thus avoid any need to specify the relevant constitution relation (whether mereological or teleological; causal or otherwise). While Madhyamaka thinkers are not unified in their conceptions of the ultimate/conventional distinction, it is arguable that for Nāgārjuna even causal relations have only conventional status within Madhyamaka ontology (see Garfield 1995). Whether "causal or constitutive," a Buddhist eudaemonist could thus argue that the relations between wisdom, virtue and mindfulness to the good life, eudaimonia, are conventional and thus legitimate within a Madhyamaka ontological framework. Given that Flanagan makes frequent appeal to the notion of conventional truth when depicting Buddhist notions of personal identity, there is (weak) reason to suppose he might prefer this strategy. ${ }^{3}$

\footnotetext{
3 The reason is only weak because, while Nāgārjuna is most famously identified with the ultimate/conventional distinction, given its centrality to MMK, it is not a distinction unique to Madhyamaka. The distinction can be found in the early recordings of the Buddha's teachings. Indeed, Vasubandhu, himself, offers a version of this distinction in his Abhidharmakośabhāṣyam. Simply
} 
There are difficulties with this Madhyamaka approach, however. One difficulty is that the Madhyamaka denial of ultimately real causal relations depends on rejecting a reductive base of causally related simple entities with svabhāva or selfnature. Given that, as mentioned above, few contemporary metaphysicians or physicists are likely to accept this particular form of essentialist ontology, its implausibility would give them no reason to be anti-realists about causation, let alone constitution. If Flanagan's objective is to extract a truthful and useful Buddhism that is "compatible with the rest of knowledge as it now exists" (xiii) then he needs to provide an argument which motivates conventionalizing causation and constitution in terms that have contemporary purchase (i.e. for reasons that do not rely on the implausibility of an ontology that no contemporary reductionist would accept). Such an argument can potentially be made. Scientific anti-realists, inspired by bridge law problems between competing physicalist explanations and who defend a Humean view of causation, are likely to resist the plausibility of a singular explanatory base of atomic entities (however construed) in causal relations. Their arguments are not decisive but may offer a reasonable starting place for such a defense. The point, however, is that some defense is needed.

Even if one could get around that hurdle, there is at least one final difficulty that relates much more closely to the objectives of BB; namely, establishing the conventional status of specifically normative claims. Even if one could convincingly legitimate the conventionality of a particular causal ontology, it is not obvious that the same arguments could be used to legitimate wisdom, virtue or mindfulness as either conventional causes or conventional constituents of conventional Buddhist eudaimonia. Consider, for instance, the Prāsañgika Madhyamaka of Candrakīrti. According to Tom Tillemans, Candrakīrti was quietist in his conventional metaphysics. He adopted a methodology of lokaprasiddha (viz. "what is acknowledged by the world') and thus advocated the acceptance of whatever the ordinary person on the street affirms as existent and as causally related (see Tillemans 2010-11, 2011). Does fire cause smoke? Yes. Are seeds disposed to sprout in suitable conditions? Sure. The plausibility of this quietist ontology depends on the intuitive plausibility of a set of folk ontological beliefs in a shared world that is populated (at least) with mid-sized things (fire, smoke, seeds, sprouts) in causal relations. The thought underlying this approach to Madhyamaka is that Ābhidharmikas get paradoxically entangled when they attempt to analyze these ordinarily related things into an ultimately real reductive base. They would be much better off leaving ordinary, everyday folk physicalist beliefs alone.

The Prāsañgika Mādhyamika does not, and cannot, take the same stance with respect to ethical norms and practices, however (see Finnigan forthcoming). They do not insofar as the descriptions of virtues that we find in Madhyamaka Buddhist texts (let alone the vinaya precepts, some version of which were adhered to by some Mādhyamikas) are conceived to have normative bearing on how one should live and act. While Prāsangika Mādhyamikas may not argue with the ordinary folk in their beliefs about the physical world, they do not thereby adopt their way of life. That they cannot simply accept the ordinary folk conceptions of ethical conduct follows from the fact that it is not clear that there $i$ s a folk morality equivalent to the folk physicalist view of a shared world populated by things in causal relations. Metaphysical disputes may occur at the privileged domain of philosophy (a domain the sensible 
Mādhyamikas can and should leave behind, according to Prāsangika) but moral disagreements occur amongst the folk. Simply conventionalizing the "causal or constitutive" relationship between wisdom, virtue and mindfulness to Buddhist eudaimonia is not going to be a straightforward matter.

Now, what is the upshot of this extended discussion? It is to clearly demonstrate that careful argument is needed to square the constitutive relation assumed by contemporary eudaemonistic reconstructions of Buddhist ethics with established Buddhist metaphysical theories. While I am personally sympathetic to non-consequentialist analyses of Buddhist ethical thought, I believe and hope to have demonstrated that establishing the consistency of Flanagan's Buddhist eudaimonia with any of a number of Buddhist metaphysical positions will take considerable work. This point bears not only on attempts to provide a rational reconstruction of Buddhist ethical thought that is systematically consistent with Buddhist metaphysical assumptions but also on contemporary attempts to unify a eudaimonistic ethical theory with a reductive ontology of personal identity.

As a final rejoinder, it might be argued that Flanagan need not engage with the intricacies of Buddhist metaphysical debates given his (more humble) objective of (merely) introducing secular-minded thinkers to a naturalized Buddhism that avoids the kind of epistemically questionable commitments that may have prevented their taking the tradition seriously. And, with regards to this more humble objective I believe that $\mathrm{BB}$ is successful. It does, indeed, convey a richer conception of Buddhist thought than held by one blinded by images of floating deities and the notion of karmic consequences. However, BB has a more ambitious audience in mind; namely, analytic philosophers to whom it aims to introduce Buddhist ethics, metaphysics and epistemology. The meta-ethical tension between a 'Lockeian' reductive ontology and an 'Aristotelian' eudaimonistic ethical theory is likely not to be lost on the contemporary Western metaphysician or ethicist. Such philosophers are likely to be dissatisfied by the level of critical engagement of these positions and their relations offered by BB. In not engaging with Buddhist philosophical literature, BB makes Buddhist thought appear much more simplistic and homogenous than it is in fact. And this is unfortunate as an introduction to Buddhist philosophy.

The Bodhisattva's Brain aims to introduce secular-minded thinkers to Buddhist thought and motivate its acceptability to a naturalistically minded analytic philosopher. It also provides a well-argued caution against the hasty generalizations of the 'science of happiness' literature. While it does not engage with Buddhist thought at its most rigorous, or as rigorously as it could, The Bodhisattva's Brain nevertheless provides a sufficiently detailed sketch for fruitful philosophical engagement. 


\section{BIBLIOGRAPHY}

\section{Primary Texts}

AKB = Abhidharmakośabhāṣyam of Vasubandhu ed. Prahlad Pradhan, Patna: Jayaswal Research Institute 1995

- English Translation of Chapter 9.1: Duerlinger, James, trans. (2009) in Buddhist Philosophy: Essential Readings, Garfield and Edelglass (eds.), Oxford

- English translation of Chapter 9.2: Kapstein, Damien, trans. (2001), Reasons Traces: Identity and Interpretation in Indian and Tibetan Buddhist Philosophy, Wisdom

MMK = Mūlamadhyamakākarika of Nāgārjuna

- English translation from Tibetan: Garfield, Jay (1995) The Fundamental

Wisdom of the Middle Way, Oxford

\section{Secondary Literature}

Ariew, A., R. Cummins, et al., eds. (2002). Functions: New Essays in the Philosophy of Psychology and Biology. Oxford; New York, Oxford University Press.

Choi, Sungho (2012), "Dispositions" Stanford Encyclopedia of Philosophy http://plato.stanford.edu/entries/dispositions/\#DisDis

Cowherds, T. (2010) Moonshadows: Conventional Truth in Buddhist Philosophy. New York, Oxford University Press.

Hallisey, C. (1996) "Ethical Particularism in Theravāda Buddhism” Journal of Buddhist Ethics 3: 32-43.

Finnigan, Bronwyn (forthcoming) "Meta-ethics for Madhyamaka: investigating the justificatory grounds of moral judgments"

--- (2010-11) "Buddhist Meta-Ethics" Journal for the International Association of Buddhist Studies, 33(1-2): 267-297

Godfrey-Smith, P. (1993). "Functions: consensus without unity" Pacific Philosophical Quarterly 74.

--- (1994). "A modern history theory of functions" Nous 28(3): 344-362.

Jerryman, M. and Juergensmeyer, M. eds. (2010) Buddhist Warfare, Oxford

Siderits, Mark. (2003) Empty Persons: Personal Identity and Buddhist Philosophy. Aldershot, Burlington: Ashgate

Sperling, Elliot (1996) “ 'Orientalism' and Aspects of Violence in the Tibetan Tradition" in Imagining Tibet: Perceptions, Projections and Fantasies, in Thierry Dodin \& Heinz Räther (eds.), Wisdom Publications

Thackchoe, Sonam (2011) "The Theory of Two Truths in India" Stanford Encyclopedia of Philosophy, http://plato.stanford.edu/entries/twotruthsindia/\#AabSarVai

Tillemans, T. J. F. (2010-11) "Madhyamaka Buddhist Ethics" Journal of the International Association of Buddhist Studies 33(1-2): 359-381.

--- (2011) "How Far Can a Mādhyamika Buddhist Reform Conventional Truth? Dismal Relativism, Fictionalism, Easy-Easy Truth, and the Alternatives." in Moonshadows: Conventional Truth in Buddhist Philosophy. Cowherds. New York, Oxford University Press: 151-165.

Westerhoff, Jan, (2009) Nāgārjuna's Madhyamaka. A Philosophical Introduction, Oxford: Oxford University Press. 